\title{
傾斜を持つだ円形介在物における引張負荷による影響*
}

$$
\text { 野口哲 雄*1, 江 角務*2 }
$$

\section{Influence on the Tensile Load in Inclination Elliptic Inclusion}

\author{
Tetsuo NOGUCHI*3 and Tsutomu EZUMI \\ ${ }^{* 3}$ Graduate School in Shibaura Institute of Technology, \\ 3-9-14 Shibaura, Minato-ku, Tokyo, 108-8548 Japan
}

\begin{abstract}
All structures have the potential to contain inclusion. Tensile load was given to inclusion. High stress appeared on the matrix in the circumference of the inclusion, which exfoliates from the matrix due to the high stress. Cracks them appeared on the matrix, gradually spread and destroyed the structure. This study researched elliptic inclusion in the tensile load. The direction of the tensile load is defined in the zero. Elliptic inclusion has some angle value. Studies on inclination elliptic inclusion did not exist until today. This study used the photoelastic method, method of caustics and finite element method. There are a few studies on inclusion by the experimental analysis but experimental analysis is difficult. However, this study identified a method for the experimental analysis of inclusion. If this method is used, results can easily be obtained by the experimental analysis of inclusion. As a result of this study, an elliptic inclusion equation was obtained. Elliptic inclusion can approximate all inclusions, and the result of this study can be applied to all inclusions.
\end{abstract}

Key Words: Experimental Stress Analysis, Stress Concentration, Finite Element Method, Photoelastic Method, Method of Caustics, Inclusion, Tensile Load

\section{1.}

構造体における介在物は構造体を破壊に至らせる原 因となる．介在物を含有する粠造体が負荷を受けたと き介在物周辺の母材に高い応力が発生する，過去にお いて体積力法による研究 ${ }^{(1)}$, 有限要素法による研究 ${ }^{(2)}$ が見られる.しかし光弾性法による研究 ${ }^{(3)}$ 等は少なく， 介在物に関する実験的㭘討が不足していると思われ る.介在物の形状に関して円形(4)，㑯斜を有しないだ 円形 ${ }^{(5)}$ ，六角形 ${ }^{(6)}$ 等がほとんどであり，傾斜を有する だ円形に関する検討は見られない，傾斜を有するだ円 形介在物は実機材における様々な形状の介在物を近似 的にモデル化できると思われる.

本研究は光力学を主体とし, 有限要素法を併用する ことにより引張負荷を受ける傾斜を持つだ円形介在物 について，次の 3 項目の解析を試みた。

（1）介在物を含有する試倹片モデルによる引張試㕉に 光弾性法を適用し，等色線縞写真と荷重一変位線図を 得る。等色線縞写真より态力集中部の主応力差を求め, 荷重一変位線図と試跧片モデルを锤察することにより 破壞過程を求めた。同様に有限要素法により解析し， 応力集中部の主応力差と相当応力を求めた.

（2）長期問における負荷により界面に脆性き裂が発生

* 原稿受付 2003 年 4 月 16 日.

*1 正員, 芝浦工業大学大学院 $108-8548$ 東京都港区芝浦 39-14).

*2 正員, 芝浦工業大学丁:学部.

E-mail : m602103@sic.shibaura-it.ac.jp
した状態をモデル化した試験片モデルに負荷を与え; 光弾性法を適用して等色線縞写真を得る. 等色線編写 真より応力拡大係数を得る。

（3）塑性城において界面が剥離し，き裂が発生した状 態をモデル化した試験片モデルに負荷を与え光弾性法 を適用し，等色線編写真を得る，き裂先端における応 力拡大係数を得る。

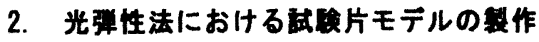

図 1 に示す JIS7 号引張試験片モデルを使用した. 母材の平行部長さについては文嗝 ${ }^{(7)}$ に従った。 介在物 の寸法, 界面の状態，き裂について表 1 に示す. 本 研究では，(a)介在物と母材の界面が接着されたモデ ル(表 1 ,No.1-1 3-13)，（b)界面が剥離し，き裂が発 生したモデル(表 1, No.4-1 〜 6-13)，（c)界面は接着さ れた状態でき裂が発生したモデル(表 1 ,No.7-1 7-3），の3 種類のモデルを用意した.

材料の特性值を表 2 に示す，母材をポリカーボネ 一ト(透明,板厚 6mm,JIS K 6899-1-PC) により製作し, 介在物の材料としてエポキシ樹脂(透明,板厚 $6 \mathrm{~mm}$,JS $\mathrm{K}$ 7238-1-EP),アクリル(透明,板厚 $6 \mathrm{~mm}, \mathrm{JIS} \mathrm{K}$ 6717-1-PMMA),ポリエチレン(透明,板厚 $6 \mathrm{~mm}$,JIS K 6922-1-PE)の 3 種を使用した。 母材と介在物の製作に おいて電子制御工作機械 (MDX-15，Roland DG 社)を 使用した. 
Table 1 Data of test specimen model

\begin{tabular}{|c|c|c|c|c|c|c|c|c|c|c|}
\hline \multirow{14}{*}{ Shape data } & \multicolumn{7}{|c|}{ No. } & $2 a[\mathrm{~mm}]$ & $2 b[\mathrm{~mm}]$ & $\theta[\mathrm{DEG}]$ \\
\hline & $1-1$ & $2-1$ & $3-1$ & $4-1$ & $5-1$ & $6-1$ & $7-1$ & \multirow{13}{*}{8} & \multirow{4}{*}{5} & 0 \\
\hline & $1-2$ & $2-2$ & $3-2$ & $4-2$ & $5-2$ & $6-2$ & $7-2$ & & & 30 \\
\hline & $1-3$ & $2-3$ & $3-3$ & 43 & $5-3$ & $6-3$ & $7-3$ & & & 60 \\
\hline & $1-4$ & $2-4$ & $3-4$ & $4-4$ & $5-4$ & $6-4$ & 7.4 & & & 90 \\
\hline & $1-5$ & $2-5$ & $3-5$ & $4-5$ & $5-5$ & $6-5$ & $7-5$ & & \multirow{4}{*}{6} & 0 \\
\hline & 1.6 & $2-6$ & $3-6$ & $4-6$ & $5-6$ & $6-6$ & $7-6$ & & & 30 \\
\hline & $1-7$ & $2-7$ & $3-7$ & 4-7 & $5-7$ & $6-7$ & 7.7 & & & 60 \\
\hline & 1.8 & $2-8$ & $3-8$ & 4-8 & $5-8$ & $6-8$ & $7-8$ & & & 90 \\
\hline & $1-9$ & $2-9$ & $3-9$ & 4-9 & $5-9$ & $6-9$ & $7-9$ & & \multirow{4}{*}{7} & 0 \\
\hline & $1-10$ & $2-10$ & $3-10$ & $4-10$ & $5-10$ & 6-10 & $7-10$ & & & 30 \\
\hline & $1-11$ & $2-11$ & $3-11$ & $4-11$ & $5-11$ & $6-11$ & $7-11$ & & & 60 \\
\hline & $1-12$ & $2-12$ & $3-12$ & $4-12$ & 5.12 & $6-12$ & $7-12$ & & & 90 \\
\hline & $1-13$ & $2-13$ & $3-13$ & $4-13$ & $5-13$ & $6-13$ & 7.13 & & 8 & $=$ \\
\hline \multirow{2}{*}{ Inclusion data } & \multicolumn{3}{|c|}{ Glued inclusion } & \multicolumn{3}{|c|}{ Inserted inclusion } & Glued inclusion & & & \\
\hline & Epoxy resin & PMMA & Polyethylene & Epoxy resin & PMMA & Pol yethylene & Epoxy resin & & 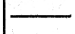 & - \\
\hline Crack data & \multicolumn{3}{|c|}{ No crack } & \multicolumn{4}{|c|}{ With the crack } & & & \\
\hline
\end{tabular}

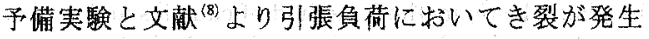
する位㽡は図 2 に示す $P_{1}$ 部であり，き裂を有する試 験片モデルにおいて, 治具を使用して極細系のこ(刃 厚 $0.18 \mathrm{~mm}, \mathrm{FFC}$ 社)を案内することにより $P_{1}$ 部に直 線状人工さ裂（長さ $3 \mathrm{~mm}$ )を挿入した.

接着界面を有する陚験片モデルにおいてエポキシ系 接着剂を使用し，母材に介在物を接着した。 24 時間 放置するこしにより接着剂を硬化させ，機械加工等に おける残留応力を除去するために，全ての轼験片モデ ルにおいて図 3 に示すアニーリングを施した。 2 段の 温度一定部を有するアニーリングサイクルにより，介 在物を含有する試験片モデルにおける残留応力を除去 可能である.アニーリング後の等色線縞写真を図 4 に示す。等色線が見られないことより残留応力が除去 されたことが分かる。

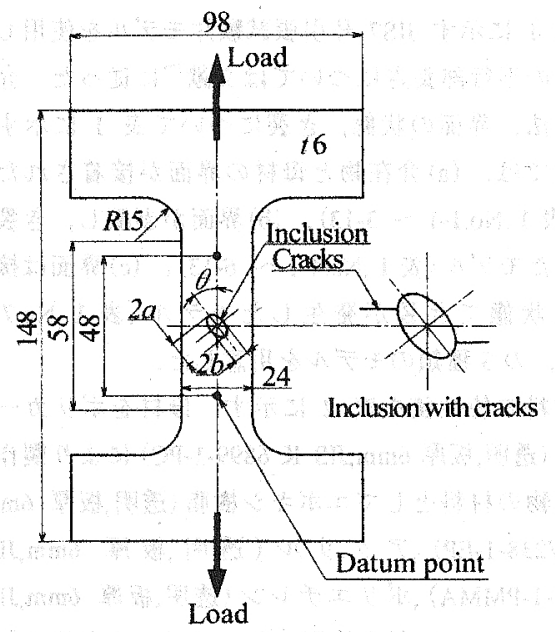

Fig.1 Test specimen model ( JIS No.7)
Table 2 Material data

\begin{tabular}{c|c|c|c}
\hline \hline Part & Material & Modulus of elasticity [MPa] & Poisson's ratio \\
\hline Matrix & Polycarbonate & 2600 & 0.36 \\
\hline \multirow{3}{*}{ Inclusion } & Epoxy resin & 3000 & 0.33 \\
\cline { 2 - 4 } & PMMA & 3200 & 0.38 \\
\cline { 2 - 4 } & Polyethylene & 600 & 0.46 \\
\hline
\end{tabular}

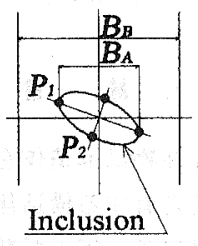

Fig. 2 Inclusion

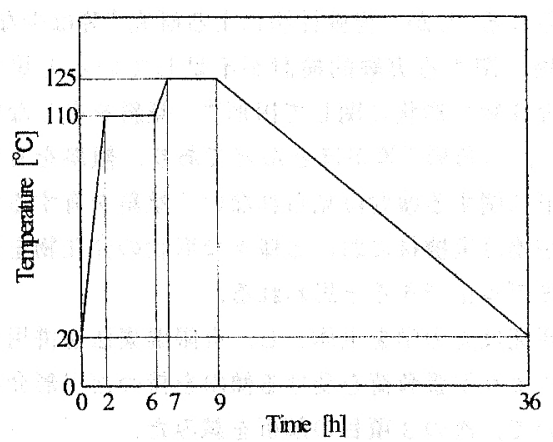

Fig.3 Annealing cycle

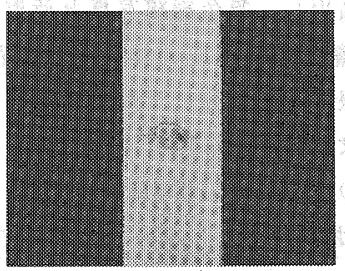

Fig.4 Isochromatic line (After the annealing) 
Table 3 Data of finite element model

\begin{tabular}{|c|c|c|c|c|c|c|c|c|}
\hline \multirow{14}{*}{ Shape data } & \multicolumn{3}{|c|}{ No. } & $2 a[\mathrm{~mm}]$ & $2 b[\mathrm{~mm}]$ & $\theta$ [DEG] & Node & Element \\
\hline & $8-1$ & $9-1$ & $10-1$ & \multirow{13}{*}{ 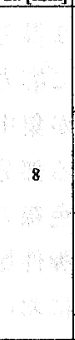 } & \multirow{4}{*}{5} & 0 & 269 & 502 \\
\hline & $8-2$ & $9-2$ & $10-2$ & & & 30 & 565 & 1060 \\
\hline & $8-3$ & $9-3$ & $10-3$ & & & 60 & 557 & 1048 \\
\hline & $8-4$ & $9-4$ & $10-4$ & & & 90 & 267 & 498 \\
\hline & $8-5$ & $9-5$ & $10-5$ & & \multirow[t]{4}{*}{ is } & 0 & 265 & 494 \\
\hline & $8-6$ & $9-6$ & $10-6$ & & & 30 & 563 & 1060 \\
\hline & $8-7$ & $9-7$ & $10-7$ & & & 60 & 565 & 1064 \\
\hline & $8-8$ & $9-8$ & $10-8$ & & & 90 & 297 & 510 \\
\hline & $8-9$ & $9-9$ & $10-9$ & & \multirow{4}{*}{7} & 0 & 291 & 502 \\
\hline & $8-10$ & $9-10$ & $10-10$ & & & 30 & 561 & 528 \\
\hline & $8-11$ & $9-11$ & $10-11$ & & & 60 & 561 & 1056 \\
\hline & $8-12$ & $9-12$ & $10-12$ & & & 90 & 291 & 498 \\
\hline & $8-13$ & $9-13$ & $10-13$ & & 8 & $=$ & 287 & 494 \\
\hline \multirow{2}{*}{ Inclusion data } & \multicolumn{3}{|c|}{ Glued inclusion } & & & & & \\
\hline & Epoxy resin & PMMA & Polyethylene & & سـ & - & 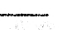 & 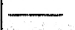 \\
\hline Crack data & \multicolumn{3}{|c|}{ No crack } & & & & & \\
\hline
\end{tabular}

\section{3. 有限要乘法における解析モデルの作成}

光弾性法において使用した武験片モデル No.1-1 3-13 をモデル化した 2 次元有限要素解析モデルを作 成した，要素分割を図 5 に示し，要素数等を表 3 に 示す。平面応力モデルである，介在物周辺における要 素を細かく分割することにより，目的とする介在物周 辺について詳細に解析した。

\section{4. 王ルによる解析}

4.1 引張試験 接着界面を有する介在物を含有 する試験片モデル No.1-1 3-13 に対し, 引張試験機 (Model 210, Intesco 社)により引張負荷を与え光弹性 法を適用し，等色線縞写真と何重一変位線図を得る。

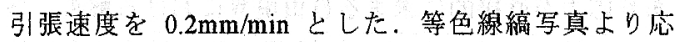
力集中部の主応力差を求めた，荷重一変位線図と試験 片モデルの観察により破壊過程を調べた。

比較のために介在物を含有しない試験片モデルと有 限要素法により解析した。

4.2 塑性域に関する解析 4.1 より塑性域におい て界面が剥離し，き裂加発生すると分かった，界面が 剥離し，き裂が発生した状態を可能な限り再胃した試 験片モデルNo.4-1〜 6-13 に光弾性法を適用した。等 色線縞写真を撮影し，応力桩大係数を求めた。裂先 端における応力集中を確認するためにへリウムーネ才 ンガスレーザー光線を使用した発散光によるコーステ イックス法を併用した。

4.3 脆性破壊に関する解析長期間における繰 り返し負荷により構造体内部に疲労が生じ，き裂が発 生する、楆造体における大部分は健全な状態であるが， き裂先端のみが塑性域にある。繰り返し負荷によりき 裂は進展し，設計菏重に比して極めて低い荷重により 構造体は脆性破壊される。長期間における鿓荷により 界面にき裂が発生した状態をモデル化した試験片モデ
ル No.7-1 7-13 に光弾性法を適用し，等色線䋨写真 を撮影した。応力桩大係数を求めた。

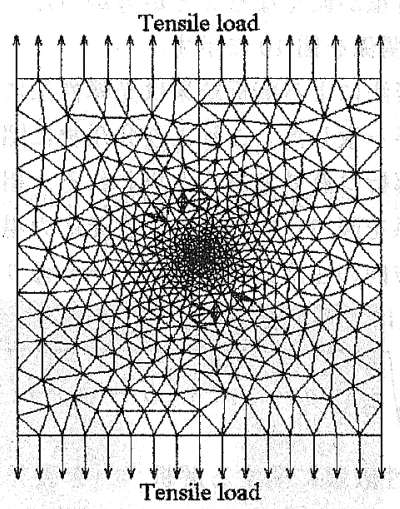

(a) All element

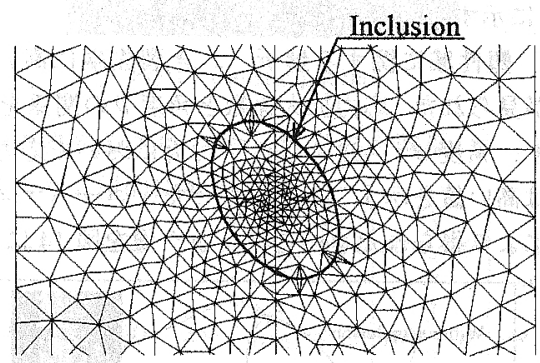

(b) Close up of inclusion

Fig. 5 Finite element model (Model No.8-2)

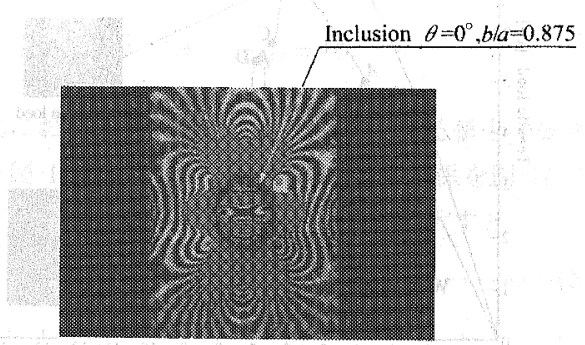

Fig.6 Isochromatic line (Model No.1-9) 


\section{5. 解析 結 果}

5.1 引張試験 光弹性法による解析より得られ た等色線編写真を図 6 に示寸. 介在物周辺に応力集 中が見られる．介在物界面において特に応力が集中す る部分を図 2 に示す。 $P_{1}$ 部はき裂が発生する部分で あり， $P_{2}$ 部は剥離が生じる部分である，等色線の推 移上荷重一変位楾図孛図 7 に示寸。点 $A$ 注弹性域で あり点 $B$ は最大荷重である。点 $B$ から点 $C$ に呫いて 介在物界面が剥離し，き裂が発生する. 点 $C$ から点 $D$ において局部的なくびれが発生し，点 $E$ において破 断した。これより引張負荷を受ける介在物において図

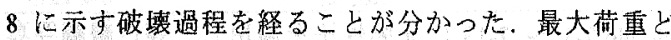
角度 $\theta$ の関係を図 9 に示す．角度 $\theta$ が大きくなるに 従い最大荷重が低くなることが分加たた，主応力差と 角度 $\theta$ の関倸を図 10 に示す。

有限要素法による解析結果は光弹性法による解析結 果と攧向が一致した。これより介在物に関する光弹性 法による解析は有效であると思われる，相当応力と角 度 $\theta$ の関係を図 11 に示す. 3 次元応力場において直 交する 3 方向の主応力 $\sigma \sigma_{1}, \sigma_{2}, \sigma_{3}$ 上り，相当応力 $\sigma y$ は次式により定義される。

$$
\sigma_{y}=\sqrt{\frac{1}{2}\left\{\left(\sigma_{1}-\sigma_{2}\right)^{2}+\left(\sigma_{2}-\sigma_{3}\right)^{2}+\left(\sigma_{1}-\sigma_{3}\right)^{2}\right\}}
$$

5.2 脆性破壊に関寸る解析き裂先端に高い応 力集中が見られた。応力桩大係数と角度 $\theta$ の関倸を 因 12 に示寸。

5.3 塑性域に関する解析 き裂先端に高い忘力 集中が見られた，応力扡大俰数と角度 $\theta$ の関係を図 13 に示方，角度 $\theta=30^{\circ}, 60^{\circ}$ 付近において応力拡大 係数惊高い值を示すことが分かった。コースティック ス法により得られたコースティック像を図 14 に示す。

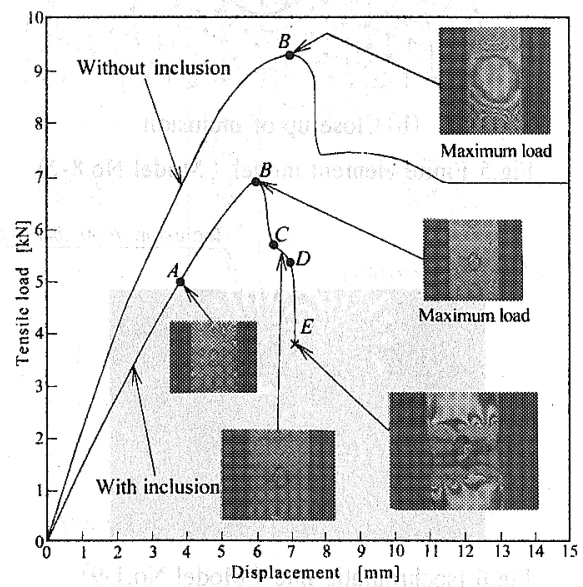

Fig.7 Relation between tensile load and displacement
き裂先端に高い応力集中が見られ， $P_{1}$ 部に発生する き裂が破壊に関倸することが分かり，5.1に执いて求 めた破壊過程と一致した。

\section{6. 拷 察}

6.1 主応力差による評価負荷を受ける材料に おける降伏条件として最大せん断応力説 (Tresca の降 伏条件) が知られる(9). 3 次元応力場において直交す る 3 方向の主応力を $\sigma_{1} ， \sigma_{2}, \sigma_{3}$ とし，相当降伏応

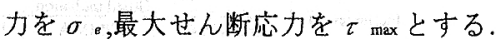

$\sigma_{1}>\sigma_{2}>\sigma_{3}$ の関倸が成立するとき, 最大せん断 忘力説による亡

$$
\tau_{\max }=\frac{1}{2}\left(\sigma_{1}-\sigma_{3}\right)=\frac{1}{2}
$$

各主応力面における主応力が存在する一般的な 2 次元応力場に最大せん断応力説を適用すると

$$
\tau_{\max }=\frac{1}{2}\left(\sigma_{1}-\sigma_{2}\right)=\frac{1}{2} \sigma_{0}
$$

式(2)上り主応力差は

$$
\sigma_{1}-\sigma_{2}=\sigma
$$

主応力差と相当降伏応力等しい状態において材料 加降伏することが分かる. 主応力差は光弾性法により 求められるパラメータである。しかし主応力差による 評価は一般的と考えられず，直応力，せん断応力によ る評価が一般的である. 光弾性法において $\sigma_{2}$ が零で あり応力が直接的に求まる自由境界における解析，多 くの時間を要する特殊な解析 ${ }^{(10)}$ が見られる，光弾性 法により自由境界以外を容易に解析する方法各必要で あり，本研究は主応力差による評価 ${ }^{(11)}$ を適用した。 光弾性法による結果と有限要素法による結果は一致し ており，主応力差による評価は有效であると思われる。 光弹性法において困難であった試験片モデル内部にお

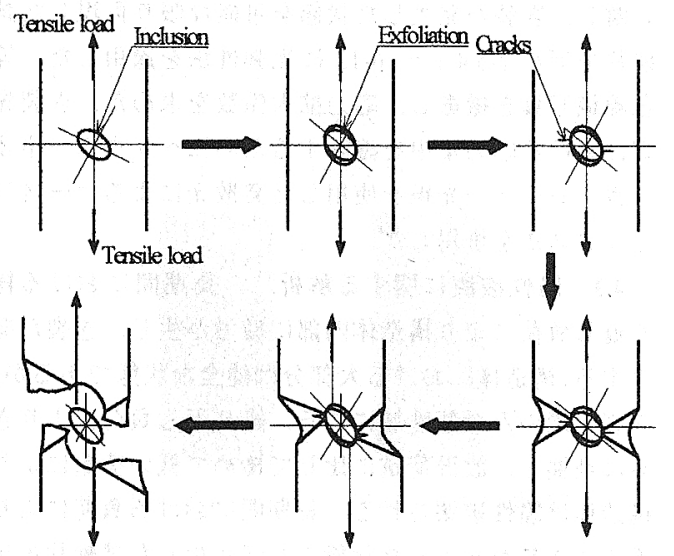

Fig. 8 Fracture 


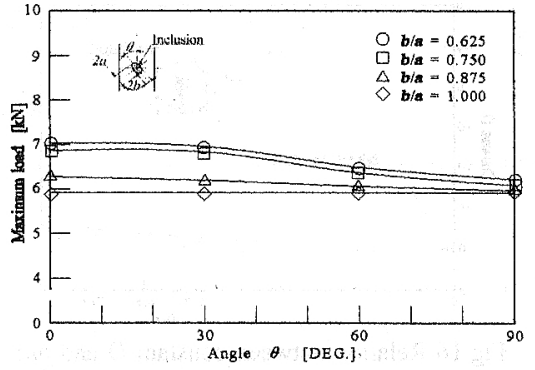

Fig.9 Maximum load (Model No.1-1 1-13)

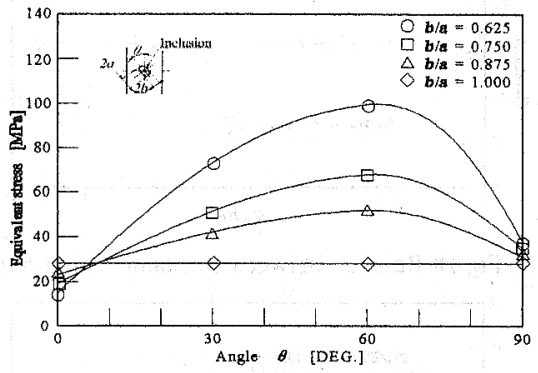

Fig.11 Equivalent stress (Part $P_{1}$, Model No.8-1 8-13)

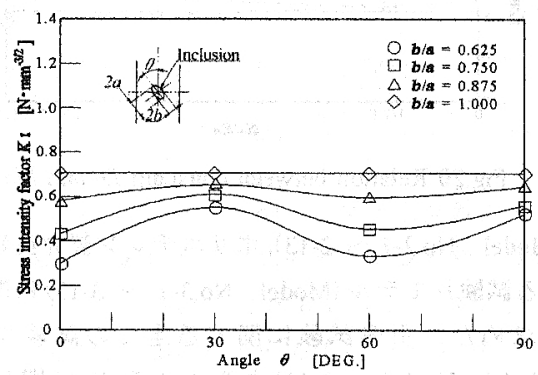

Fig. 13 Stress intensity factor $K_{1} \quad($ Model No.4-1 4-13)

ける解析が主応力による評価により容易となり，光弾 性法の適用籍囲吕搪大すると考えられる。

6.2 引張試験,塑性域に関する実駩式引張試験 における光弹性法の適用により得た $P_{1}$ 部における主 応力差を $\sigma P_{P E 1}, P_{2}$ 部における主圭力差を $\sigma P_{E E 2}$, 有限要 素法より得た $P_{1}$ 部における相当応力を $\sigma E S ， P_{2}$ 部に おける相当忘力を $\sigma$ ES2 とする。き裂を有する試験片 モデルに光弾性法を適用することによる塑性域に関す る解析により得たき裂先端における開口形応力拡大係 数を $K_{\mathrm{I}}$ ，き裂先端におけす面内せん断形応力拡大係 数を $K$ 日とする。，実験式の基本形を例えば $\sigma{ }_{P E 1} に つ$ いて次のように仮定した。

$$
\sigma_{P E 1}=A \cdot \sin (B \theta+C)+D
$$

例として光弾性法により求められた $P_{1}$ 部における 主応力差 $\sigma$ PEI に関する実験式を導く.エポキシ樹脂 製介在物を含有する試䍄片モデル(Model No.1-1

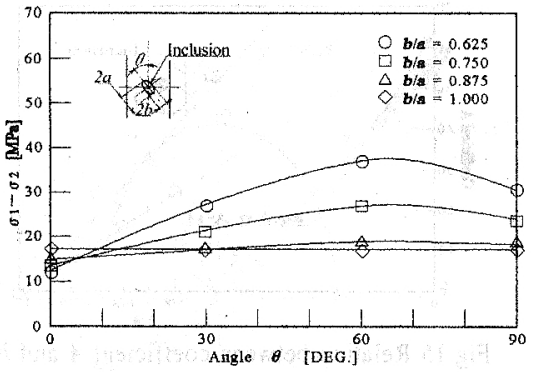

Fig.10 $\sigma_{1}-\sigma_{2}\left(\right.$ Part $P_{1}$, Model No.1-1 1-13)

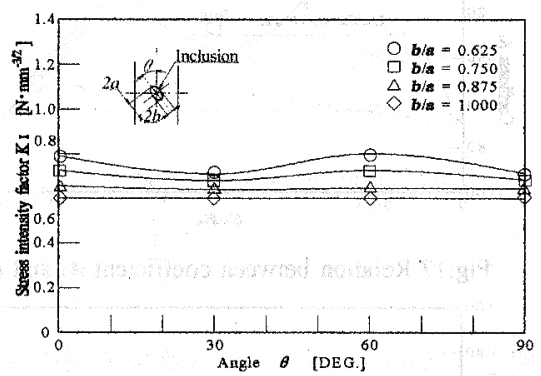

Fig. 12 Stress intensity factor $K_{\text {I }}$ (Model No.7-1 7-13)

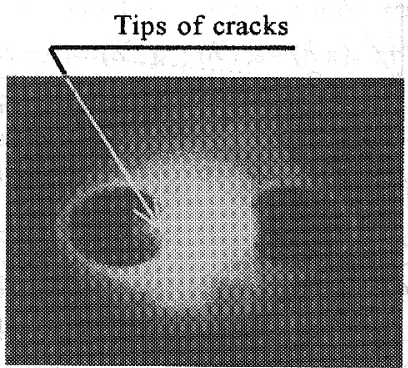

Fig.14 Caustic pattren

1-13）に関する主応力差と角度 $\theta$ の関係（図 10）を式 (4)により近似的に示すと

$$
\begin{aligned}
& b / a=0.625 \Rightarrow \sigma_{P B I}=24\left|\sin \frac{3}{2} \theta\right|+13 \\
& b / a=0.750 \Rightarrow \sigma_{P E I}=13\left|\sin \frac{3}{2} \theta\right|+14 \\
& b / a=0.875 \Rightarrow \sigma_{P E I}=2\left|\sin \frac{3}{2} \theta\right|+15 \\
& b / a=1.000 \Rightarrow \sigma_{P E I}=16
\end{aligned}
$$

上式において式(4)の係数 $A$ に相当する值と $b / a$ の 関係を図 15 に示し, 定数 $D$ と b/aの関係を図 16 に 示す. $A, D$ を 1 次方程式により近似的に示すと

$$
A=-64 \frac{b}{a}+64
$$




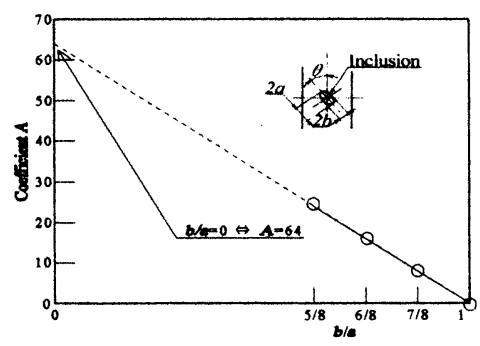

Fig.15 Relation between coefficient $A$ and $b / a$

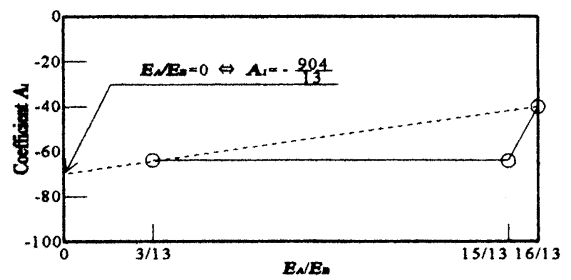

Fig. 17 Relation between coefficient $A_{1}$ and $b / a$

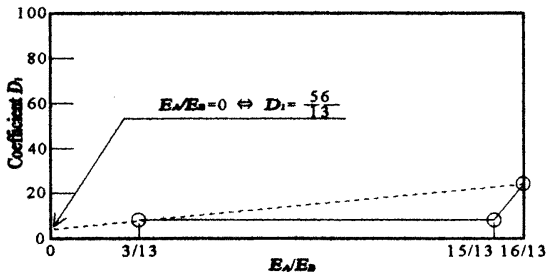

Fig.19 Relation between coefficient $D_{1}$ and $b / a$

$$
D=8 \frac{b}{a}+8
$$

$\sigma{ }_{P B I}$ の上記近似式と式(4)より $C=0$ と分かる. 式(5),式(6)を式(4)に代入すると

$$
\sigma_{P E I}=\left(-64 \frac{b}{a}+64\right)\left|\sin \frac{3}{2} \theta\right|+\left(8 \frac{b}{a}+8\right) \cdots(7)
$$

すなわち

$$
A_{1}=-64, A_{2}=64, D_{1}=8, D_{2}=8
$$

式（7）に $A_{1}, A_{2}, D_{1}, D_{2}$ を適用すると

$$
\sigma_{P E l}=\left(A_{1} \frac{b}{a}+A_{2}\right)\left|\sin \frac{3}{2} \theta\right|+\left(D_{1} \frac{b}{a}+D_{2}\right) \cdots
$$

同様にアクリル製介在物を含有する試験片モデル

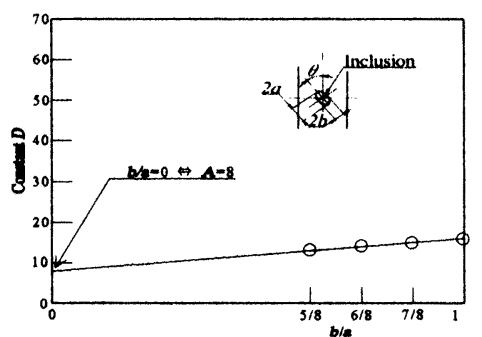

Fig.16 Relation between constant $D$ and $b / a$

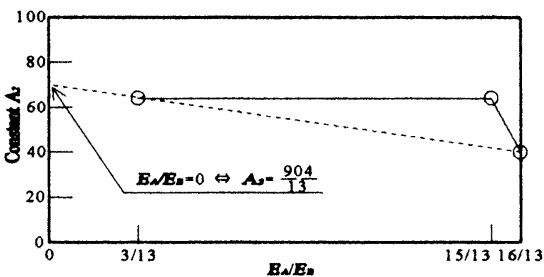

Fig.18 Relation between constantt $A_{2}$ and $b / a$

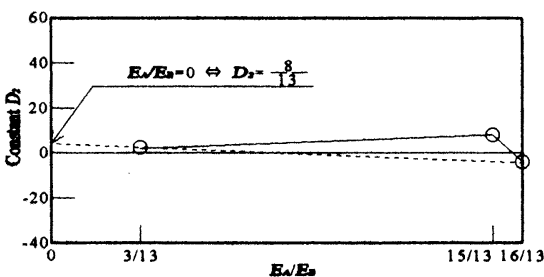

Fig.20 Relation between constantt $D_{2}$ and $b / a$

(Model No.2-1 2-13), ポリエチレン製介在物を含有 する試験片モデル(Model No.3-1 〜 3-13)に関する解 を求めた。引張試監に関する全ての試験片モデル (Model No.1-1〜 3-13) より $A_{1}, A_{2}, D_{1}, D_{2}$ に関して図 17 〜図 20 を得た。 $E_{A}$ は介在物の䋛弾性係数， $E_{B}$ は母材 の䋛弾性係数である，図 17 〜図 20 より近似的に

$$
\begin{array}{ll}
A_{1}=24 \frac{E_{A}}{E_{B}}-\frac{904}{13}, & A_{2}=-24 \frac{E_{A}}{E_{B}}+\frac{904}{13} \\
D_{1}=16 \frac{E_{A}}{E_{B}}+\frac{56}{13}, & D_{2}=-6 \frac{E_{A}}{E_{B}}+\frac{8}{13}
\end{array}
$$

$A_{1,}, A_{2}, D_{1}, D_{2}$ を式(8)に代入すると

$$
\begin{aligned}
\sigma_{P E l} & =\left\{\left(24 \frac{E_{A}}{E_{B}}-\frac{904}{13}\right) \frac{b}{a}+\left(-24 \frac{E_{A}}{E_{B}}+\frac{904}{13}\right)\right\}\left|\sin \frac{3}{2} \theta\right|+\left\{\left(16 \frac{E_{A}}{E_{B}}+\frac{56}{13}\right) \frac{b}{a}+\left(-6 \frac{E_{A}}{E_{B}}+\frac{8}{13}\right)\right\} \\
& =\left\{\left(24 \frac{E_{A}}{E_{B}}-69.54\right) \frac{b}{a}-24 \frac{E_{A}}{E_{B}}+69.54\right\}\left|\sin \frac{3}{2} \theta\right|+\left(16 \frac{E_{A}}{E_{B}}+4.308\right) \frac{b}{a}-6 \frac{E_{A}}{E_{B}}+0.6154 \ldots
\end{aligned}
$$

6.3 実臨式の一鈠化 6.2 において求められた害 験式を一般化するための係数を求めるために介在物と $P_{1}$ 部の相対位置を求める。座標軸を図 21 に示す．介 在物の陯郭は次式により求められる。

$$
\frac{x_{1}}{a^{2}}+\frac{y_{1}}{b^{2}}=1
$$

介在物の㢵部に接し， $P_{1}$ 部を通る直線は

$$
y_{1}=A_{C} \cdot x_{1}+B_{C}
$$


特に $P_{1}$ 部において式(11)は

$$
y_{C}=A_{C} \cdot x_{C}+B_{C}
$$

$y$ 軸と $x_{1}$ 軸がなす角度 $\theta_{1}$ は

$$
\theta_{1}=\frac{\pi}{2}-\theta
$$

式（12）における傾き $A c$ は

$$
A_{C}=\tan \theta_{1}
$$

式(11)における $B C$ は，式(11)を式(10)に代入し

$$
\left(\frac{1}{a^{2}}+\frac{A_{C^{2}}}{b^{2}}\right) x_{1}^{2}+\frac{2 A_{C} B_{C}}{b^{2}} x_{1}+\frac{B_{C}}{b^{2}}-1=0 \ldots
$$

式(15)において判別式により重解をとると

$$
B_{C}=\frac{1}{a b} \sqrt{\frac{1}{a^{2}}+\frac{A C^{2}}{b^{2}}}
$$

式（15）において解の公式を適用すると

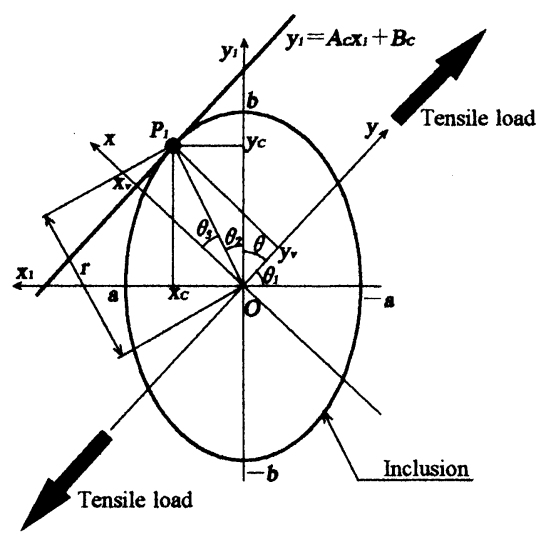

Fig.21 Relation between inclusion and $P_{1}$

$$
\left.x_{C}=\left\{-\frac{2 A C B C}{b^{2}} \pm \sqrt{\left(\frac{2 A C B C}{b^{2}}\right)^{2}-4\left(\frac{1}{a^{2}}+\frac{A c^{2}}{b^{2}}\right)\left(\frac{B C^{2}}{b^{2}}-1\right)}\right\} / 2\left(\frac{1}{a^{2}}+\frac{A c^{2}}{b^{2}}\right)\right\}
$$

式(12)に式(14),式(16),式(17)を代入すると $y_{c}$ が求 まる.介在物中心と $P_{1}$ 部の距離 $r$ は

$$
r=\sqrt{x_{C^{2}}+y_{c^{2}}}
$$

以上より $x y$ 平面における $P_{1}$ 部の $x$ 座標は

$$
x_{V}=r \cdot \cos \left(\frac{\pi}{2}-\theta-\tan ^{-1} \frac{\sqrt{y_{C^{2}-r^{2}}}}{r}\right) \cdots
$$

求められた $x_{V}$ により，実豎式に関する試験片モデ ル平行部の幅を一般化するための無欣元量を持つ係数 を求める，P、部において介在物における主応力差 $\left(\sigma_{1}-\sigma_{2}\right)_{A}$, 母材における主応力差 $\left(\sigma_{1}-\sigma_{2}\right)_{B}$, 介在 物における開口形応力应大係数 $\left(K_{\mathrm{I}}\right)_{A}$,介在物におけ

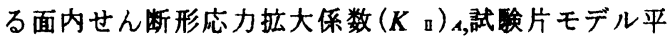
行部における開口形応力抬大係数 $\left(K_{\mathrm{I}}\right)_{B}$,試験片モデ ル平行部における面内せん断形応力拡大係数 $(K \text { I })_{B}$
と介在物の幅 $B_{A}$,試臨片モデル平行部の幅 $B_{B}$ の関係は 異種接合材における基礎理論より

$$
\begin{aligned}
& \left(B_{B}-B_{A}\right): B_{A}=\left(\sigma_{1}-\sigma_{2}\right)_{A}:\left(\sigma_{1}-\sigma_{2}\right)_{B} \cdots \\
& \left(B_{B}-B_{A}\right): B_{A}=\left(K_{\mathrm{I}}\right)_{A}:\left(K_{\mathrm{I}}\right)_{B}=\left(K_{\mathrm{II}}\right)_{A}:\left(K_{\mathrm{II}}\right)_{B}
\end{aligned}
$$

介在物の幅 $B_{A}$ は

$$
B_{A}=2 x
$$

実機材における平行部の幅を $B R M$ 試跧片モデルにお ける平行部の幅を $B_{B A}$ とすると, 式(20),式(21)より 平行部の幅に関して諸量を一般化する係数 $U$ が次の ように求められた。

$$
\begin{aligned}
U & =\frac{B_{A}}{B_{B A}-B_{A}} \cdot \frac{B_{B M}-B_{A}}{B_{A}} \\
& =\frac{24-B_{A}}{B_{B A}-B_{A}}
\end{aligned}
$$

Table 4 Influence by the tensile load in the inclination elliptic inclusion

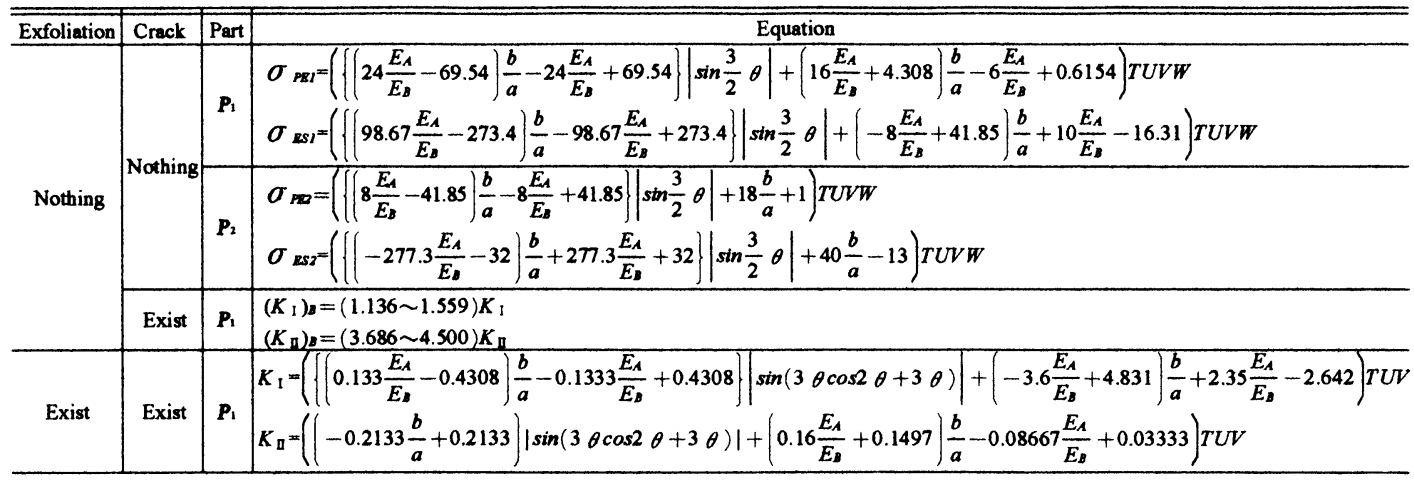


Table 5 Coefficient

\begin{tabular}{|c|c|c|}
\hline Coefficient & Step & Eqation \\
\hline \multicolumn{2}{|l|}{$\boldsymbol{T}$} & $T=\frac{t}{6}$ \\
\hline \multirow{9}{*}{$\boldsymbol{U}$} & 1 & $\theta_{1}=\frac{\pi}{2}-\theta$ \\
\hline & 2 & $\Lambda_{c}=\tan \theta_{1}$ \\
\hline & 3 & $B_{c}=\frac{1}{a b} \sqrt{\frac{1}{a^{2}}+\frac{A c^{2}}{b^{2}}}$ \\
\hline & 4 & $x_{c}=\left\{-\frac{2 A c B_{c}}{b^{2}} \pm \sqrt{\left.\left(\frac{2 A c B c}{b^{2}}\right)^{2}-4\left(\frac{1}{a^{2}}+\frac{A c^{2}}{b^{2}}\right)\left(\frac{B c^{2}}{b^{2}}-1\right)\right] /\left\{2\left(\frac{1}{a^{2}}+\frac{A c^{2}}{b^{2}}\right.\right.}\right.$ \\
\hline & 5 & $y_{c}=A_{c} x_{c}+B_{c}$ \\
\hline & 6 & $r=\sqrt{x c^{2}+y c^{2}}$ \\
\hline & 7 & $x_{V}=r \cdot \cos \left(\frac{\pi}{2}-\theta-\tan ^{1} \frac{\sqrt{y c^{2}-r^{2}}}{r}\right.$ \\
\hline & 8 & $B_{A}=2 x_{r}$ \\
\hline & 9 & $U=\frac{24-B_{A}}{B_{B A}-B_{A}}$ \\
\hline \multicolumn{2}{|l|}{$\boldsymbol{V}$} & $V=\sqrt{\frac{a_{c}}{3}}$ \\
\hline \multicolumn{2}{|l|}{$\mathbf{w}$} & $W=\frac{P}{3000}$ \\
\hline
\end{tabular}

Table 6 Variable

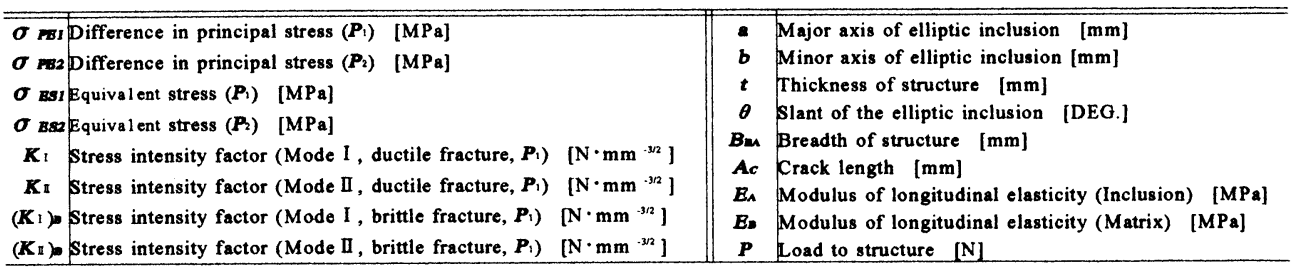

同様に実機材における板厚 $t$ ，実機材におけるき裂 長さ $a_{c}$ ，実機材における荷重 $P$ より，板厚を一般化す るための係数 $T$,き裂長さを一般化するための係数 $V$, 荷重を一般化するための保数 $W$ を求め，実機材にお ける状況に対応可能とした。

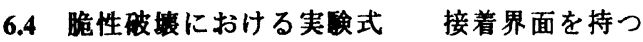
試験片モデル(Model No.7-1 7-13) と他の試験片モ デルにおける応力桩大係数 (12)を比較することにより

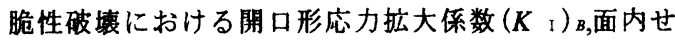
ん断形応力拡大俰数 $(\boldsymbol{K} \text { n) })_{\mathbf{B}}$ に関する実験式を得た。

6.5 総括 表 4 に示す実駼式と表 5 に示す係数 を得た，表 6 に変量を示す．プログラムを作成し， 任意の条件における值を求めると適正な值を得た．介 在物を含有し，引張負荷を受ける物体に関する解析等 に実験式を適用可能であると思われる.

\section{7. 結}

傾斜を有するだ円形介在物に関する引張負荷におけ る影䇾を調べ，次の知見を得た。

（1）だ円形介在物周辺に高い応力集中が見られ，粠造 体が破壊する可能性が高い。

（2）引張負荷における破填過程が分かった。

（3）引張方向を零とした介在物傾斜角度 $\theta$ が大きくな るに従い，最大荷重は低くなる。

(4)だ円形介在物最外部 $P_{1}$ における主応力差と相当応
力は介在物㑯斜角度 $\theta$ により大きく影䇾される。

(5) だ円形介在物最外部 $P_{1}$ における開口形応力拡大俰 数と介在物傾斜角度 $\theta$ の関保において，母材と介在物 の界面における剥離の有無により異なる㑯向を示す。

(6) 光弾性法による主応力差をパラメータとした評価 は有効であると思われる.

（7）応力集中部における主応力差,相当応力, 応力拡大俰 数に関する実験式を得た。

\section{考文}

（1）平岛健一・木村清和·広瀬幸雄，機論，57-540，A (1991), 211-218.

（2）村田雅人·向井喜彦，機論，58-555，A（1992）, 57-62.

（3）中川文人·仲野雄一·沢俊行, 機論, 58-554, A (1992), 177-183.

(4) 陳牫珎, 機論, 61-584, A (1995), 121-125.

(5) 藤本浩司, 機論, 65-640, A (1999), pp.85-93.

(6)陳玳环・西谷弘信, 機論, 57-542, A (1991), 226-230.

(7) 西谷弘信·森山稳, 機譮, 67-653, A(2001), 55-59.

(8) 村田雅人·向井喜彦, 機論, 58-555, A(1992), 57-62.

(9) 竹内洋一郎, 材料力学, (1969), 296, 日新出版.

（10）辻二郎・西田正孝・河田幸三, 光弾性実験法, (1940)，141，日刊工業新聞社。

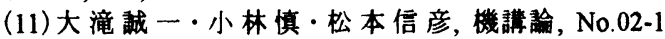
(2002-9) , 199-200.

（12）野口哲雄 - 江角務，2002 年度実酸力学会年欣講 演論文集, $(2002-8), 285-286$ : 